\title{
Public Relations Activities in an Academic Library: The Roles of the Reference Librarian
}

\author{
Odede Israel
}

Department of Library \&Information science, Delta State University, Abraka

\begin{abstract}
Library Public relations include ongoing activities to ensure the library has a strong public image. Public relations activities as they relate to the roles of the reference librarian in an academic library are discussed. The role of the reference librarian as the public relation officer of his or her library in fulfilling the objectives of the library and the institution are discussed. Great public relations can substantially accelerate library's development cycle, increase users' awareness and help promote rapid growth. Harnessing this power can be a great boost-if it is done with clear objectives by the reference librarian as discussed in this work. The importance of public relations in an academic library as well as public relations methods are also discussed in this work. This discussion highlights the function of a public relation officer in relation to the function of a reference librarian and the effect of professional variables of reference librarian on his/her job performance which will affect the library in a positive way and create a good image for the library.
\end{abstract}

Keywords Public Relations, Academic Libraries, Reference Librarian

\section{Introduction}

Public relations is a management function of continuing and planned character, through which public and private organization such as the library seek to win and retain the understanding, sympathy, and support of those whom they are or maybe concerned.

Library public relations is a deliberate, planned, and sustained effort to establish and maintain mutual understanding between the library and the publics (users) public relation activities help to provide a coordinated effort to communicate a positive image of the library and promote the availability of the library's materials, programs, and services. The importance of public relations activities cannot be overlooked in any library; especially in academic libraries. The significant of academic libraries specifically university libraries cannot be over emphasized. According to[4] university libraries assist the universities in the discharge of their functions by acquiring all relevant information resources necessary for sustaining the teaching, learning, research and public services functions of their universities. This is to say that the objectives of any academic institution cannot be achieved without the presence of public relations. Any library activity, directly or indirectly, is an act of public relations, in as much as it is done to promote the library image and use.

* Corresponding author:

israeldede@yahoo.com (Odede Israel)

Published online at http://journal.sapub.org/library

Copyright (C) 2012 Scientific \& Academic Publishing. All Rights Reserved
The reference librarian plays the role of public relations officer for the library. He goes outside the confines of the library to carve a good image of the library in the minds of the potential users. A good number of libraries especially academic libraries offer so many commercial services unknown to users; it is the duty of reference librarian to inform the public about these services. The reference librarian may use handbills to pass on information to people and advertise library services.

The reference librarian is part of the overall professionals working to bring the required desire to fulfillment and therefore has a lot to contribute to make the services of the library a success. Reference librarians can be referred to as the public relations officer of any library. He/She is the image booster to the library he or she is working for because of his/her duties, which deal directly with the users. He or She is the intermediary between the users and the library. He or She can easily know what the users need and what the library has. Therefore, the role of the reference librarian in academic libraries and its relationship with the public relations activities cannot be overstated.

[3] say:

Having services that no one

Knows about is as good as

having no service at all.

Academic libraries are very important in education institutions. However, they are not achieving their full potential because of lack of or failure of public relations. No matter how libraries respond to the needs of their users, their values will not be appreciated without an aggressive, systematic and determined programme of publicity to stimulate, inform and 
attract the information seeker/library users. Academic libraries have to covey signals and projected images to their users through public relations that accurately reflect what they are and what they do. It is true that all library professionals should be involved in public relations activities, but those professionals whose work is directly related with the users perform more of public relations activities than the other.

This article focuses on the role of a reference librarian since he or she represent the library to the users more than other partners. He is the image maker of the library.

The public relations officer in any organization is the image maker and image-bearer of such organization and therefore has many roles to play in order to ensure a good image for the organization. This will involve their relationship with those who deal with the organization and also their behaviour. The reference librarian librarians are the image makers, and indeed, the gateway through which people get in contact with the information rich environment of the library.

\section{What is Public Relations}

Public relations is a management tool that is increasingly becoming important in the management of organization such as the library, whether private or public, whether they are profit making or non profit oriented. It is an essential element in the communication system that enables individuals to be informed on many aspects of subjects that affects their lives

According to[2], the term public relation connotes;

I. Information given to the public,

II. Persuasion directed to modify attitudes and actions and

III. Efforts to integrate attitudes and actions of an institution with its public and of publics with that institution.

Public relations is a distinctive management function which helps establish and maintain mutual lines of communication, understanding, acceptance and co operation between an organization and its publics. Public relation is an activity geared towards human relationship to enhance good services.

Public relations according to[1] is defined as management functions which evaluate public attitudes, identifies the policies and procedures of an individual or an organization with the public interest and executes an understanding and acceptance. Also,[6], says:

Public relations is an activity aimed at increasing communication

And understanding between an organization or individual and one

Or more groups called publics.

Public relation uses for principal methods to communicate with the public, namely;

- Advertising

- Lobbying

- Publicity; and

- Press agents.

Reference librarians mostly used publicity and press agents to promote public relation in libraries. The same methods used in marketing are used in public relations to let people know who and what you are and to build relationships with the media. Examples include press release, newsletters, brochures, annual reports, or well-designed publications. Increasingly, libraries are utilizing interactive social media, such as blogs, twitter and facebook, as tool in their public relations campaigns. Unlike the traditional tools which allowed for only one-way communication, social media allows the library to engage in two-way communication, and receive immediate feedback from their various stakeholders and publics. Plans may include:

a. Establishing favourable press relations to get news out about the library on a regular

basis.

b. Creating publicity for specify services and resources and to create and maintain awareness of library capabilities in the institution.

c. Establishing regular communications channels to promote an understanding of your organization internally and externally.

d. Maintaining awareness of laws and regulations that affect libraries and lobbying to ensure legislation that helps libraries provide effective services.

e. Watching for community and national trends and issues that impact the library's image, and informing library administrators.

Public relations in essence, will help the library to communicate its existence to the appropriate audience, to the people for whom it has so much to offer. It is therefore necessary for reference librarians to design more extensive public relations programme that will increase public awareness of the significant contributions made by academic libraries to further the academic achievement and life long learning of students.

Hence, this article attempts to:

1. Examine the work of a public relations officer and the reference librarian.

2. Look into the effect of professional variables of reference librarian on his/her job performance.

3. Examine the role played by the reference librarian and his or her relationship with the clientele

4. Examine the importance of public relations on academic libraries.

\section{Functions of a Public Relations Officer and the Reference Librarian}

The public relations officer is one who administers policies and programs related to promotions and who maintains a relation with the local media and community groups.He is a bridge who brings together organizational activities being done in isolation. In the same vein, the reference librarian co-ordinates the services of the library at the services point. (Reference desk),making sure that the library, through the 
library assistants, discharges its duties by serving users either by providing answers to their queries or users education or creating awareness on services rendered by the library which will help to promote maximum utilization of library services and resources.

The reference librarian deals with isolated activities so as to bring them together just like a public relations officer of any organization. He acts as an intermediary between the users and the library resources making them available to users. The public relations officer tries to blow his/her organization's trumpet through the provision of information. The reference librarian disseminates the already acquired information to serve users. He is a link between the library and the outside world to make known the activities of the library which is similar to the role of a public relations officer of any organization.

[5] highlights the functions of Nigerian reference librarians among which are assistance and instruction in library use, location of materials, use of the catalogue, and use of basic reference tools and sources. They also provide brief, factual information of the ready reference type, conducting literature searches, interlibrary loans for users, selective dissemination of information to clients and public relations.

The reference librarian just like public relations officer of any organization advertises the library by employing public relations tools such as:

. Library signage (layout);

. Holding of library exhibitions;

. Media talks;

. Notice board for both staff and students;

. Bulleting boards;

. Suggestion boxes; and

. Public information desks e.t.c

Every library has public relation in the sense that it has a relationship with the community that it serves but how mutual is the relationship that exist is the concern of the library management. Some academic libraries have the information unit as part of their public relations programme. This makes the job of the reference librarian easier. The reference librarian just like the public relations officer of any organization ensures that users and potential users of the library have untrammeled access to resources which he or she does through active promotion of the use of information and library. He or she gathers information related to the activities of the library, this information is then organized for publication purposes to promote the image of the library.

\section{Effect of Professional Variables of Reference Librarian on His/Her Job Performance}

The reference librarian success in handling reference services judiciously from various positions will lead to the general success of the library. The job performance of the reference librarian will be determined by the professional variables such as service attitude exhibited by the reference librarian.

The successful reference professional cares about clients and enjoy face to face interactions. He/she is not judgmental and cheerful serves all regardless of their appearance or status. His/her styles and manner keep clients at ease. He/she is careful to ensure that users do not lose face. He/she is never too busy to help and walks the floor when the press of business allows. The reference librarian encourages interaction and participation. He/she keeps the client informed of what she is doing and why.

The reference librarian is able to explain what has been done, and why, if possible, the librarian contacts users to see if their needs were met and if they were successful. In particular, he/she avoids premature recommendations. Each encounter with a user ends with proper closure which is public relations in display. In all of the above, body language is extremely important. Success in public service requires:

.Warmth greetings

. Eye contact

. Smiles

. Friendly voice

. Cheerful face

Customers see and hear variety of cues that tell them if the reference librarian is genuinely interested in their queries or not. It is hard to hide disinterest or boredom. The reference librarian must be a good listener. Active listening is a skill that can be learned and sharpened. As the intermediary between the users and the library, it requires that the reference librarian should focused attention on the user regardless of the circumstances. Good listening skills will help the reference librarian to perform his or her public relations function well.

Putting the user at ease and good listening are preconditions for reference service. Still, being able to ask the right question in the right manner makes all the difference in the world of reference service. To understand the needs of users, you must ask a question about the situation that generated it. Users may not wish to reveal the situation because of privacy and loss of face issues. In few cases, users may reveal more than the professional wishes to hear.

To understand the need, you must understand how the client is going to use the information sought. Again privacy issues can be a concern. The skillful questioner will be able to establish rapport and ask questions in a natural and non -threatening way. To help the client, you must know what she or he has already done (prior search history) this question needs to be handled in such a way that the user does not lose face or feels inadequate. Without some skill by the reference librarian, this type of question can be seen as a put down by the user. The reference librarian ability to paraphrase the user's question is often useful. It demonstrates to the user that the reference librarian is focused and paying attention.

Competence is another professional variable that affect job performance of the reference librarian. The successful reference professional is familiar with a broad range of reference sources in different formats. His or her knowledge of 
local and some distant collections is substantial. He or she has an active current awareness program to keep up with new resources. In addition to his or her general knowledge, he or she is more familiar with some subject areas likely to interest the university community members. The reference librarian is able to match resources to queries and knows how to use these resources effectively. Competence also includes his or her knowledge of the reference interview and an ability to discover what information is needed.

The environment where the interaction occurs plays a substantial role in success. A friendly and attractive environment will attract users and more questions. A dark and unfriendly environment may limit use to the hard core user. Also, a logical, highly visible arrangement should make it easy to find help and particular items in collections. Service points should be well marked and highly visible.

The reference librarian can help to bring awareness of the library stocks and services by employing service tools and making use of them effectively. Such tools as current awareness services, selective dissemination of information or exhibitions have a very important aspect to play in public relations activities of the reference librarian. Through exhibitions, library services and programmes can be given publicity. The reference librarian must be engaged in exhibitions which can be used to publicize library stocks. The reference librarian must create an awareness forum, such as an orientation week, education programme for old and new users.

A good reference librarian should master the reference tools in the library. He should be patient, non-abrasive, and polite, and needs to have empathy. Furthermore, he should readily get out of his office to direct the clientele to the shelves and even assist them locate materials which they need to consult to satisfy their information needs. Cheerfulness is also essential for pragmatic reference work. By wearing a smile on the face during a reference transaction, the reference librarian quells the anxiety of the inquirer.

Above all, the reference librarian should be able to communicate effectively; he must understand the language of the profession. He or she must create an opportunity to talk to potential and actual users about the services render by the library. This is also part of the reference librarian's public relations activities. The reference librarian should be friendly to all users; also, they must be approachable for any queries, simple to complex. The reference librarian can help and thereby save users from frustration through public relations tools.

\section{Importance of Public Relations in Academic Libraries}

The prime aim of any academic library is to satisfy its users by providing materials to meet their educational, research, information and recreational needs. The library cannot achieve these aims without 'good will' and co-operation of its publics. Thus, the library needs public relations in its effort to achieve its aims. Therefore, high quality book stock supplemented by personal contact through public relations is a necessary requirement.

The importances of public relations in academic libraries are as follows:

1.Public relations influences and create confidence for library services in the public in various ways, such as making the public aware of the services and policies of the library. Develop knowledge and understanding of a new reorganization or new initiative introduced by the library.

2.Public relations helps in opening up the world of books and knowledge better and more completely than would otherwise be possible by bringing together clientele, collections and services. It helps to make better contact between the library staff and the public, so that what is known can be enlarged upon and used more fully.

3. Public relations bring about co-operation among professional colleagues creating a sense of oneness thereby improving relationship. This relationship can lead to mutual collaboration wherein one library receives and extends help from and to another library.

4.Public relations helps to make better contact between the librarians and the public, this give the librarian opportunity to create a good image of the library which can lead to an increase in the utilization of library services and resources.

5. In academic institution, there is a tendency for people especially students to be stuck in grooves and become dull and lazy about the academic work. A public relations that is well conceived and carried out can help correct such negative tendencies and become a means for energizing people to creating better harmony.

6. Public relations help to keep tab on the external environment so as to gather outside opinions/comments and pass on this information to the library management for possible consideration.

7. Public relations in an academic library will help to keep the various publics informed about policy, functions and services of the library as well increase the staff knowledge and understanding.

8. Good public relations will help librarians get more support from their parent organizations and the public in terms of personnel, budgets and equipment. It is believed that improving librarians living and working conditions depends to a great extent on librarians themselves persuading, explaining and bargaining.

9. Quite a number of new students do not know what a library is, what services it provides, or what benefits they can gain from it, public relations will help to publicize and market the functions and services of the library.

10. In Nigeria, most academic library's social image is not very good. Public relations as the art of portraying an image should change what people formerly thought of the library by improving our services and communicating with readers, in order to enlarge the library's influence within society.

\section{Role of the Reference Librarian and}




\section{His or Her Relationship with the User/Clientele}

The primary function of a reference librarian of any library is answering user query. Reference librarians have inherent obligations to provide information service to support the educational, recreational, personal and economic endeavours of their user communities as appropriate to the missions of the library. The reference librarian establishes a mutual relationship with the users and always appears welcoming in order for the user to find it easy to approach the reference desk. Cheerfulness is also essential for pragmatic reference work and mutual relationship between the reference librarian and the user. Furthermore, he should readily get out of his desk to direct the clientele to the shelves and even assist them locate materials which they need to consult to satisfy their information needs.

He or she serves people who work independently to find information, but who need a little help from time to time. The reference librarian as part of his public relations activities teaches users regularly how to make effective use of the library and the need to obey library rules and regulations. Since the existence of the reference librarian is to assist the user, he also make an arrangement of inter - library loans since library can hardly meet all the information needs of her clientele as no library is self sufficient in meeting users needs. The book from where they exist and inturn lends them to his patrons who have requested them. Also to serve the users better, the reference librarian constantly compiles bibliographies for quick access to information use by the clientele.

The current awareness services rendered by the reference librarian is of great importance to the users as it helps in keeping up to date with the current literature in a particular subject. Readers can be informed through library public relation activities such as display of new books and other information forums (printed communications such as newsletters annual reports, press releases etc)

The reference librarian also performs a guiding role by assisting the users to rephrase his or her question(s) in order for such question to be meaningful and then directing the user to appropriate information resources. Assisting the users to rephrase his or her question is one of the most important works a reference librarian does, because this enables the reference librarian to match the patron's question to a relevant and useful source. He or she will be in a good position to determine what resource is capable of handling such query. Also, another guiding role of the reference librarian is to make readers aware of the technicality of library usage through issuing of library guide or handbook.

The reference librarian provides reading guidance to individual. Readers' advisory involves recommending to users what they might read. The reference librarian also play the role of building collection for the library and the user by selecting, evaluating and recommending relevant materials not only for the reference collection but the library collection as a whole. This is in order to ensure that there are relevant and adequate resources in the library to meet users' information needs. The reference librarian can also liaise with the acquisition department to purchase on time or process on time books in high demand by the users. This is made possible if the reference librarian knows his or her users' profile.

\section{Conclusions}

There is the need for increased interest in public relations in libraries generally especially academic library. Public relations in an academic library will help to establish the library's image and position within the academic community. Since academic library support lifelong learning, public relations will help in opening up the world of books and knowledge better and more completely than would otherwise be possible by bringing together clientele, collections and services.

There is the need for academic libraries to employ public relations as it will help to make better contact between the library staff and the public, so that what is known can be enlarged upon and used more fully. To achieve the objectives and goals of the library, the library staff especially the reference staff should take seriously public relations activities. The reference librarian plays the role of a public relations officer as he or she act as a bridge who brings together library's activities being done in isolation, co-ordinates the services of the library at the service point (reference desk), and blow the library's trumpet through the provision of information. The reference librarian therefore, is a link between the library and the outside world, to make known the activities of the library. Therefore, in whatever type of library one serves, public relations should be regarded as a prerequisite for the effective functioning of the library and which will help to promote the services of the library.

\section{REFERENCES}

[1] Aitufe, T.A.'Public relations in academic libraries', Library Review, Vol. 42 No. 2, pp. 39-45.1993

[2] Chai, Y. (1996), 'Review of library public relations studies', Library and Information Service, No. 2.1996.

[3] Chen,C.C. and Hernon,P., information-seeking:Assessing and Anticipating user needs,Applications in information Technology series,Neal-Schuman, New York, NY.1982.

[4] Dodsworth, E.M., ' Marketing academic libraries: a necessary plan', The Journal of Academic Librarianship, Vol. 24 No. 4, pp.320.1998.

[5] Lawal Olu Olat, Reference services in Nigerian Libraries, In S.O.Olanlokun and T.M.Salisu (Eds), Libraries and Librarianship in Nigeria: A Festschrift for Ezekiel Bejide Bankole. Lagos: Ikofa Press Limited, pp.49-59.2001

[6] World Book, World Book Encyclopaedia,vol.15,Part 3, World Book Inc,Scott Fetzer Co.,Chicago,IL, p.868.2002. 